Apidologie, 1979, 10 (1), 43-53.

\title{
MICROBIOLOGY OF POLLEN AND BEE BREAD : THE YEASTS
}

\author{
Martha GILLIAM \\ U.S. Department of Agriculture \\ Science and Education Administration \\ Bee Research Laboratory \\ 2000 East Allen Road \\ Tucson, Arizona 85719
}

\begin{abstract}
SUMMARY
One-hundred and thirteen yeasts belonging to seven genera were isolated from almond (Prunus communis) pollen from the flower, from pollen pellets from traps placed on bee (Apis mellifera) hives in the orchard, and from pollen stored in comb cells of the hive (bee bread) for one, three, and six weeks. Torulopsis magnoliae was the most common isolate and was found in all pollen samples except pollen from the flower. Thus, the bees may have added it to the pollen. The number of isolates and species decreased with time and storage. In general, most of the yeast species from pollen from the flower and the trap were not found in bee bread. Also, yeast isolates from pollen from the flower and the trap fermented more sugars and assimilated more carbon compounds than those from bee bread.
\end{abstract}

\section{INTRODUCTION}

The nutritional requirements of honey bees, Apis mellifera, are met by the collection of pollen, nectar, and water. Nectar is the primary source of carbohydrates; pollen provides proteins, lipids, vitamins, and minerals. Foraging worker bees collect pollen that is then packed into cells of the brood comb by other, generally younger, bees, and a small cover of honey is deposited on the pollen to prevent spoilage. This store of pollen, which has undergone chemical changes, is called bee bread. Bee bread is consumed by adult bees and is fed to larvae.

Pollen and bee bread, differ biochemically. For example, bee bread contains more reducing sugars than pollen from the same plant species (CASTEEL, 1912). Also, bee bread contains vitamin K (HAYDAK and VIVINO, 1950) and a milk-digesting 
enzyme (HIтcHсOCK, 1956); pollen collected from the legs of foraging bees does not. Avetisian (1935) found that bee bread made from birch pollen contained six times as much lactic acid as hand-collected birch pollen.

The conversion of pollen to bee bread and the accompanying biochemical changes have often been postulated to be the result of microbial action, principally a lactic acid fermentation caused by bacteria and yeasts (Foote, 1957; HAYDAK, 1958). CHEvtchiK (1950) conducted microbiological analyses of fresh pollen and pollen stored in comb cells and reported four phases of microbial development in fermenting pollen that occurred during seven days from the time of the appearance of lactic acid bacteria, yeasts, indole-producing bacteria (Escherichia), and sporulating aerobic bacteria. The first phase lasted 12 hours and was characterized by the development of a heterogenous group of microorganisms including yeasts. In the second phase, anaerobic lactic acid bacteria (Streptococcus) utilized growth factors produced by the yeasts and putrefactive bacteria and lowered the $\mathrm{pH}$ of the pollen. The third phase was characterized by the disappearance of Streptococcus and the development of Lactobacillus that produce more acid than Streptococcus. The fourth phase, which began at the end of the seventh day, was characterized by the disappearance of the lactic acid bacteria and certain yeasts due to the large quantity of lactic acid produced. The pollen became microbially sterile, and the $\mathrm{pH}$ was approximately 4. During the course of this study, CHEvtCHIK isolated from fresh and fermented pollen 77 groups of yeasts that he considered to be sources of proteins, lipids, and necessary growth factors.

PAIN and MAUGenet (1966) reported that three microbial genera (Lactobacillus, Pseudomonas, and Saccharomyces) were important in the modification of pollen during storage. Lactobacillus caused a lactic acid fermentation that stabilized the pollen by increasing the acidity, but the roles of Pseudomonas and Saccharomyces were not well understood. They thought that pseudomonads probably contributed to the anaerobiosis required by Lactobacillus and to the degradation of the walls of pollen grains since they developed rapidly as soon as the pollen was packed by bees into comb cells but disappeared almost totally after two to three days. Then lactic acid was produced by Lactobacillus. This lactic acid fermentation was completed by the end of about 15 days though the responsible organisms maintained a stationary population for several months. The yeasts, which were present in small numbers initially, increased after fermentation and subsisted in stored pollen longer than other organisms. These researchers seeded pollen sterilized by gamma irradiation with Lactobacillus and concluded that a pure lactic acid fermentation produced an unappetizing product of poor nutritive value for bees. Thus, they thought that the yeasts played the most important role from the nutritional standpoint. It has also been reported that the enzyme systems involved in the fermentation of pollen are similar to yeast enzyme systems (OKUNUKı, 1943). 
EGoRova (1971) isolated a bacterium that she named Lactobacterium pollinis from bee bread samples collected in the spring and summer. This organism occurred either in pure culture or in mixed cultures with yeasts. In a mixed culture with the yeasts the bacterium survived for up to six months without subculturing. However pure culture Lactobacterium pollinis had to be subcultured every 30 days. Thus, it would seem that the yeasts were either using the lactic acid produced by the bacterium or were providing necessary growth factors.

Table 1 summarizes the available literature on yeasts isolated from pollen and bee bread. Yeasts belonging to 12 genera have been identified. Other researchers noted yeasts in pollen and bee bread, but the organisms were not identified (BETTS, 1928; LEMOS and MACHADO, 1975; WILSON and MARVIN, 1929).

Since relatively little is known about the microbiology of pollen and bee bread and since the yeasts seem to be important in the elaboration of bee bread, I examined pollen and bee bread for these organisms. In this paper, bee bread is defined as pollen packed by bees in comb cells of the hive.

\section{MATERIALS AND METHODS}

Fifteen colonies of bees were placed in an almond, Prunus communis, orchard in February 1976 in the vicinity of Davis, California; almond pollen was collected hourly from pollen traps placed on these hives. The pollen was frozen in liquid nitrogen within 15-30 minutes after collection and was stored in a freezer until used. On the basis of uniform color and size of the pellets, the pollen collected was at least $99.8 \%$ almond pollen.

Also, four colonies of honey bees were established in September 1976 on new equipment and were maintained in a polyethylene green house. Each hive contained nine frames, one with sealed and unsealed brood and the others containing only newly drawn combs. At four-hour intervals two almond pollen pellets were placed into each cell on both sides of three newly drawn combs from each hive. During the four-hour intervals, the bees packed the pollen into the cells. After two three days, most of the comb cells were at least 1/2-3/4 filled with packed pollen. The bees had access only to water and the almond pollen. Then three combs from each colony containing the packed pollen were placed in a clean room maintained at $34{ }^{\circ} \mathrm{C}$ and $55-60 \%$ R.H. to stimulate storage in the hive and to avoid possible overgrowth of the pollen by molds.

The following samples of almond pollen were collected for analyses : fresh pollen collected by hand from the flower in March 1977; pollen pellets removed from the bees' legs by traps placed on hives in the almond orchard; and bee bread stored in comb cells for one, three, and six weeks. Each bee bread sample was a composite collection from all the combs that contained pollen pellets.

Each pollen or bee bread sample was divided into four sub-samples of approximately $0.75 \mathrm{~g}$ each. Then each of the four sub-samples was homogenized by hand in $2.5 \mathrm{ml}$ of sterile $0.85 \% \mathrm{NaCl}$ in a glass tissue grinder. The homogenates were plated $(0.1 \mathrm{ml})$ in duplicate on acidified yeast extract-malt extract agar containing $1 \%$ glucose, $\mathrm{pH}$ 3.7-3.8 (YMA) (MILLER et al., 1976). One plate from each subsample was incubated at $26^{\circ} \mathrm{C}$ and one at $37^{\circ} \mathrm{C}$ under aerobic conditions. When yeast colonies appeared, they were checked for purity and transferred to slants of YMA and yeast extract-malt extract agar with $1 \%$ glucose (YM-1) (WICKERHAM, 1951). Morphological and physiological tests were conducted according to WICKERHAM (1951), and isolates were identified according to BARNETT and PANKhurst (1974) and LodDer (1970). 
TABL. 1. - Yeasts previously isolated from pollen and bee bread

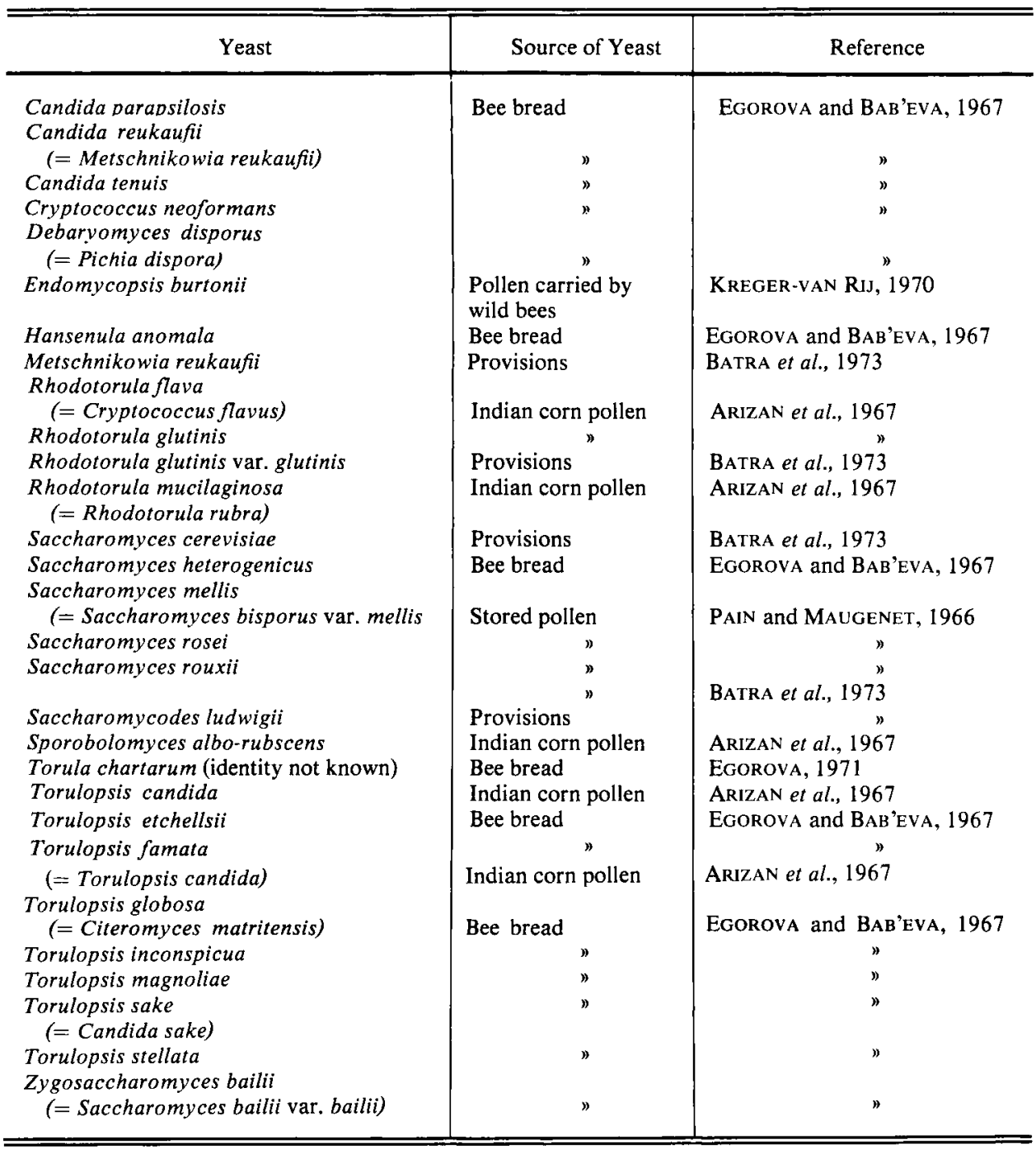

\section{RESULTS}

One-hundred and thirteen yeasts were isolated by the sampling procedure used, and 110 were identified (Tabl. 2). The three yeasts that I was unable to identify were different species. The unidentified isolate from bee bread stored in the comb for three weeks was a pink mucoid yeast that did not grow in the medium used for assimilation 
TABL. 2. - Yeasts isolated from almond pollen and bee bread.

\begin{tabular}{|c|c|}
\hline Yeasts & $\begin{array}{c}\text { Number of } \\
\text { isolates }\end{array}$ \\
\hline \multicolumn{2}{|l|}{ Isolates from pollen from the flower } \\
\hline $\begin{array}{l}\text { Cryptococcus albidus var. albidus } \\
\text { Kloeckera apiculata } \\
\text { Cryptococcus albidus var. diffluens } \\
\text { Candida guilliermondii var. guilliermondii } \\
\text { Rhodotorula pilimanae } \\
\text { Torulopsis norvegica } \\
\text { Candida parapsilosis } \\
\text { Cryptococcus laurentii var. laurentii } \\
\text { Hansenula anomala var. anomala } \\
\text { Rhodotorula glutinis var. glutinis } \\
\text { Rhodotorula rubra } \\
\text { Unidentified }\end{array}$ & $\begin{array}{l}8 \\
5 \\
4 \\
4 \\
2 \\
2 \\
1 \\
1 \\
1 \\
1 \\
1 \\
2\end{array}$ \\
\hline \multicolumn{2}{|l|}{ Isolates from pollen from the bees' legs } \\
\hline $\begin{array}{l}\text { Candida guilliermondii var. guilliermondii } \\
\text { Torulopsis magnoliae } \\
\text { Metschnikowia pulcherrima } \\
\text { Rhodotorula glutinis var. glutinis } \\
\text { Rhodotorula pallida }\end{array}$ & $\begin{array}{r}19 \\
10 \\
1 \\
1 \\
1\end{array}$ \\
\hline Isolates from bee bread stored in the comb for 1 week & \\
\hline $\begin{array}{l}\text { Torulopsis magnoliae } \\
\text { Cryptococcus flavus } \\
\text { Cryptococcus laurentii var. magnus } \\
\text { Rhodotorula glutinis var. glutinis }\end{array}$ & $\begin{array}{r}21 \\
1 \\
1 \\
1\end{array}$ \\
\hline Isolates from bee bread stored in the comb for 3 weeks & \\
\hline $\begin{array}{l}\text { Torulopsis magnoliae } \\
\text { Cryptococcus albidus var. albidus } \\
\text { Unidentified }\end{array}$ & $\begin{array}{l}9 \\
2 \\
1\end{array}$ \\
\hline Isolates from bee bread stored in the comb for 6 weeks & \\
\hline $\begin{array}{l}\text { Torulopsis magnoliae } \\
\text { Cryptococcus albidus var. diffluens } \\
\text { Cryptococcus albidus var. albidus }\end{array}$ & $\begin{array}{l}9 \\
3 \\
1\end{array}$ \\
\hline
\end{tabular}

tests; it produced acid without gas in the fermentation tubes containing glucose, galactose, maltose, sucrose, melibiose, and raffinose. Neither of the two unidentified isolates from pollen from the flower fermented any of the sugars that were tested, but both assimilated a large number of carbon compounds. 
Torulopsis magnoliae was the most common isolate and was found in all pollen samples except pollen from the flower. Candida guilliermondii var. guilliermondii was the second most common isolate but was found only in pollen from the flower and pollen from the trap. Cryptococcus albidus was isolated a total of 18 times from pollen from the flower and from bee bread stored for 3 weeks and 6 weeks. Most of the other isolates were obtained from pollen from the flower.

The number of isolates and species decreased with time and storage (Tabl. 3). Pollen from the flower contained the most species though this sample and pollen from the trap yielded an equal number of isolates. Thus, almond pollen from the flower contained a diverse yeast flora that diminished upon collection by bees and storage in the hive. Torulopsis magnoliae was the predominant isolate from bee bread.

TABL. 3. - Numbers of yeast species and isolates from almond pollen and bee bread.

\begin{tabular}{l|c|c}
\hline \multicolumn{1}{c|}{ Source of pollen } & Total species isolated & Total isolates \\
\hline Flower & 12 & 32 \\
Pollen trap & 5 & 32 \\
Comb cells after 1 week & 4 & 24 \\
Comb cells after 3 weeks & 3 & 12 \\
Comb cells after 6 weeks & 2 & 13 \\
\hline
\end{tabular}

\section{DISCUSSION}

Yeasts belonging to seven genera were isolated from almond pollen and bee bread. Organisms belonging to Torulopsis, Candida, and Cryptococcus comprised $85 \%$ of the isolates. Torulopsis magnoliae was the most common isolate representing $43 \%$ of the yeasts. This organism was also the most common yeast isolate from the guts of adult worker honey bees in Arizona (Gilliam et al., 1974; Gilliam et al., 1977). Since T. magnoliae was not found in pollen from the flower but first appeared in trapped pollen and was then found in all bee bread samples, the bees may have added it to the pollen. Also, biochemical changes that occurred in trapped pollen and bee bread obviously allowed the organism to flourish.

New records of yeasts from pollen and bee bread are Candida guilliermondii var. guilliermondii, Cryptococcus albidus var. albidus, Cr. albidus var. diffluens, $\mathrm{Cr}$. laurentii var. laurentii, Cr. laurentii var. magnus, Kloeckera apiculata, Metschnikowia pulcherrima, Rhodotorula pallida, $R$ h. pilimanae, and Torulopsis norvegica. Of these, C. guilliermondii, Cr. albidus, Kl. apiculata, and $M$. pulcherrima have been isolated from honey bees (see Gilliam et al., 1974). 
All the isolates but two (Hansenula anomala var. anomala and M. pulcherrima) were asporogenous. Sporulating yeasts are not often found in bees (EGorova and BAB'eVA, 1967; Gilliam et al., 1974; Gilliam et al., 1977) or bee bread (Egorova and BAB'EVA, 1967). Candida guilliermondii contains strains that are incapable of mating; mating strains of $C$. guilliermondii are classified in the heterothallic species Pichia guilliermondii. Thus, $P$. guilliermondii is the perfect form of $C$. guilliermondii var. guilliermondii. Microscopic observations of cultured mixtures of my strains of $C$. guilliermondii var. guilliermondii did not reveal any indication of conjugation or sporulation. This is not surprising since most strains of the organism have been found to be sexually unreactive (WICKERHAM and BURTON, 1954).

Candida guilliermondii var. guilliermondii was the second most common isolate but was found only in pollen from the flower and from the pollen trap. Thus, bee bread was not a suitable environment for this organism. In general, most of the yeasts from pollen from the flower and trap were not found in bee bread, although $\mathrm{Cr}$. albidus and Rh. glutinis var. glutinis were found in both. Thus, the physical and chemical properties of pollen and bee bread may influence the composition of the yeast flora.

Chevtchik (1950) observed that most of the yeasts isolated from fresh and fermented pollen did not ferment any sugars. However, Egorova and BAB'Eva (1967) found that the majority of species they isolated fermented those sugars found in the bee colony or nectar, specifically glucose, sucrose, and maltose. Some of the isolates fermented galactose, but the enzyme splitting lactose was absent in almost all the yeasts isolated. They concluded that the yeast flora of the honey bee colony consists of species adapted to live in the medium and that the epiphytic yeast species of insect-pollinated plants enter the yeast flora of bee intestines and are also found in bee bread. Similarly, WILSON and MARvin (1929) had also reported that none of the yeasts they isolated from pollen and bee bread fermented lactose, although glucose and sucrose were fermented. A few of the isolates fermented raffinose, maltose and galactose.

My results on the fermentative properties of yeasts from pollen and bee bread are in agreement with those previously reported. None of the isolates fermented lactose. Only one yeast, $H$. anomala var. anomala, from pollen from the flower, fermented maltose. Isolates from pollen from the flower and the trap fermented more sugars that those from bee bread. Over half of these isolates fermented glucose and sucrose. Some also fermented galactose, melibiose, and raffinose. However, if gas is produced in the tube containing raffinose, the yeast may be fermenting the raffinose molecule $1 / 3,2 / 3$, or completely (VAN DER WALT, 1970). Eighty percent of the isolates from bee fermented glucose and sucrose; no other sugars tested were fermented. Of the total isolates from all sources, $72 \%$ fermented glucose, and $65 \%$ fermented sucrose.

Eighty-three percent of the isolates grew in the osmotic pressure medium. Only two isolates, both from the flower, grew at $5{ }^{\circ} \mathrm{C}$, but $66 \%$ of the isolates grew at 
$37^{\circ} \mathrm{C}$. However, the ability to grow at this higher temperature was most evident in yeasts isolated from pollen from the trap and bee bread stored for one week.

Carbon assimilation tests used in yeast taxonomy are more sensitive than fermentation tests for detecting the presence of yeast enzyme systems (WiCKERHAM, 1951). These tests employ a chemically defined medium to which a single organic compound is added as the sole source of carbon. A standardized suspension of the yeast to be tested is then added to the medium. Assimilation reactions test the ability or inability of a yeast to use a specific carbon compound oxidatively. I routinely use the 38 carbon compounds listed by WiCKERHAM (1951).

Although fewer yeasts were isolated from bee bread ( 49 minus one that did not grow in the assimilation medium) than pollen (64), $50 \%$ more of the isolates from pollen than from bee bread assimilated maltose, cellibiose, trehalose, melezitose, Dxylose, D-arabinose, D-ribose, L-rhamnose, ethyl alcohol, and adonitol. Forty percent more of the pollen isolates than bee bread isolates assimilated melibiose, $\mathrm{L}$ arabinose, D-glucosamine hydrochloride, alpha-methyl-D-glucoside, pyruvic acid, and DL-lactic acid. In fact, none of the isolates from bee bread assimilated lactic acid, although $42 \%$ of those from pollen did. Inulin, soluble starch, dulcitol, calcium 2keto-D-gluconate, and citric acid were also assimilated by a larger percentage of isolates from pollen than bee bread. Percentages of the other compounds assimilated by isolates from pollen and from bee bread differed by less than $25 \%$, and most differed by $10 \%$ or less.

Thus, a larger percentage of yeasts from pollen from the trap and from the flower assimilated more carbon compounds and fermented more sugars than did those from bee bread. More of these compounds may be available in pollen than bee bread. The number of yeast species also decreased in bee bread. Therefore, the biochemical changes that have occurred in bee bread may limit the species of yeasts that are able to survive. If the yeasts are responsible for biochemical changes in pollen as it converted to bee bread, then these changes may start to occur as soon as the bees touch the pollen to pack it in the pollen baskets on the legs. Foote (1957) speculated that stored pollen could be inoculated with microorganisms by the bees as it is mixed with nectar or regurgitated honey both while the foraging bee moistened the grains to make a suitable mass to carry to the hive and during packing of the pollen into a comb cell by other bees in the hive.

Egorova (1971) noted that yeasts form vitamins, mainly those of the B group, in bee bread and were therefore necessary for honey bees. She also thought that lactic acid bacteria obtain vitamins and amino acids from yeasts. СнеvтсHIK (1950) examined eight groups of yeasts from pollen and bee bread and found that seven grew without vitamins, and one did not. The vitamin deficiency test revealed that $13 \%$ of my isolates grew in the absence of vitamins. Thus, they were capable of synthesizing all the vitamins required for growth. Most of these yeasts were isolated from pollen from the flower and the trap. 
Starch was synthesized by $17 \%$ of the isolates, although no yeasts from pollen from the trap or from bee bread stored for one week possessed this ability. Gelatin was liquified by $15 \%$ of the isolates indicating that proteases were produced by some isolates from all samples.

Because the $\mathrm{pH}$ of the pollen and bee bread samples was 4.2-4.5, a favorable environment for the growth of fungi existed. LAvIE (1960) reported that pollen collected by bees contains an active antibiotic factor that is derived both from the plant and from the bee. However, pollens do not contain any anti-fungal substances. Therefore, the years and molds are not affected.

When reporting the results of microbiological analyses of pollen, one should always give the pollen species and source. For example, PAIN and MaUgenet (1966) emphasized that their results on microflora of pollen and bee bread were probably valid only for their region or for a region of similar climate. Thus, my results revealed a more diverse yeast flora than reported by other workers. However, the role of yeasts in biochemical modifications of pollen and in bee nutrition are not defined (PAIN and MAUGENET, 1966). Hopefully the present paper will encourage other researchers from other regions to examine the yeast flora of bees, pollen, and bee bread. Only after thorough microbiological analyses have been completed can work begin on the contribution of specific groups of microorganisms to bee nutrition.

Received for publication in August 1978.

\section{ACKNOWLEDGMENTS}

I thank Mrs. Dinorah Dunham for her excellent technical assistance; Dr. L. N. STANdifer, Mr. Harold Don, and Mr. John Mills for the pollen samples; Dr. L. J. Wickerham for microscopic examination of the yeasts; and Mrs. Rachael Algaze for translating into English the paper by PAIN and MAUGENET.

\section{ZUSAMMENFASSUNG}

\section{DIE MIKROBIOLOGIE VON POLLEN UND BIENENBROT : DIE HEFEN}

Die folgenden Proben von Mandelpollen (Prunus communis) wurden auf das Vorkommen von Hefen untersucht: Handgesammelter Pollen aus den Blüten; Pollenhöschen, mittels Pollenfallen an den Bienenkästen in der Mandelkultur unmittelbar von den Beinen der Bienen abgestreift; und Bienenbrot, in den Wabenzellen für eine, drei und sechs Wochen gelagert. Homogenate von jeder Probe wurden auf angesäuerten Hefeextrakt-Malzextrak-Agar mit $1 \%$ Glukose ausgebracht.

Es wurden 113 verschiedene Hefen isoliert, und 110 von ihnen wurden identifiziert. Mandelpollen aus den Blüten enthielt eine vielfältige Hefenflora, die sich nach der Einsammlung durch die Bienen und Einlagerung im Volk verringerte. Organismen aus den Genera Torulopsis, Candida und Cryptococcus stellten $85 \%$ der Isolate. Am häufigsten war Torulopsis magnoliae mit $43 \%$ sämtlicher Hefen. Da diese Art im Pollen aus den Blüten nicht gefunden wurde, sondern erstmals im Pollen aus der Pollenfalle und dann in sämtlichen Proben von Bienenbrot, könnte es sein, dass sie von den Bienen in den Pollen gebracht worden war. 
Candida guilliermondii var. guilliermondii war das zweithäufigste Isolat, aber es wurde nur im Pollen aus der Blüte und aus der Falle gefunden. Bienenbrot war also kein geeignetes Milieu für diesen Organismus. Ganz allgemein kann gesagt werten, dass die meisten Hefen aus dem aus Blüten oder aus der Falle stammenden Pollen im Bienenbrot nicht gefunden wurden.

Aus Blüten oder aus der Pollenfalle stammende Pollenhefen fermentierten eine grössere Anzahl von Zuckern und assimilierten mehr Kohlenstoffverbindungen als Hefen aus Bienenbrot. Keine der Hefen fermentierte Laktose und nur ein einziges Isolat fermentierte Maltose. Die biochemischen Veränderungen, die im Bienenbrot erfolgen, scheinen also die Zahl der Hefearten, die imstande sind zu überleben, zu beschränken.

\section{RESUME \\ MICROBIOLOGIE DU POLLEN ET DU PAIN D'ABEILLES : LES LEVURES}

On a recherché les levures dans les échantillons suivants de pollen d'amandier (Prunus communis): pollen récolté à la main sur les fleurs, pelotes de pollen prélevées sur les pattes des abeilles par des trappes placées sur les ruches dans le verger d'amandiers, pain d'abeilles stocké dans les cellules des rayons pendant une semaine, trois semaines ou six semaines. Des homogénats de chacun de ces échantillons ont été déposés sur agar à l'extrait de levures acidifié et à l'extrait de malt, renfermant $1 \%$ de glucose.

Cent trente levures ont été isolées et cent dix déterminées. Le pollen d'amandier prélevé sur les fleurs renfermait une flore diversifiée de levures, qui diminuait suite à la récolte par les abeilles et au stockage dans la ruche. Les organismes appartenant aux genres Torulopsis, Candida et Cryptococcus constituaient $85 \%$ des isolats. Torulopsis magnoliae, l'isolat le plus commun, représentait $43 \%$ des levures. Puisqu'on ne l'a pas trouvé dans le pollen prélevé sur les fleurs, mais qu'il est apparu pour la première fois dans le pollen récolté par trappes et a été retrouvé ensuite dans tous les échantillons de pain d'abeilles, ce sont les abeilles qui ont dû l'ajouter au pollen.

Candida guilliermondii var. guilliermondii vient en seconde position, mais n'a été trouvé que dans le pollen prélevé sur les fleurs et dans celui récolté par trappes. Le pain d'abeilles est donc un milieu qui ne convient pas à cet organisme. En général la plupart des levures présentes dans le pollen de fleurs et le pollen de trappes n'ont pas été retrouvées dans le pain d'abeilles.

Les levures provenant du pollen de fleurs et du pollen de trappes ont fait fermenter plus de sucres et ont assimilé plus de composés carbonés que celles provenant du pain d'abeilles. Aucune des levures n'a fait fermenter le lactose et un seul isolat a fait fermenter le maitose. Il se peut donc que les changements biochimiques qui surviennent dans le pain d'abeilles limitent les espèces de levures capables de survivre.

\section{REFERENCES}

Arizan D., Popa A. Mitroiu P., Toma C., Serban M., Crisan I., Dobre V., 1967. - Conservation du pollen par des radiations ionisantes. Bull. Apicole, 10, 43-50.

Avetisian G. A., 1935. - Recent work on the chemical composition of pollen. Bee World, 16, 92.

Barnett J. A., Pankhurst R. J., 1974. - " A New Key to the Yeasts », North-Holland, Amsterdam.

Batra L. R., Batra S. W. T., BoharT G. E., 1973. - The mycoflora of domesticated and wild bees (Apoidea). Mycopathol. Mycol. appl., 49, 13-44.

BETTS A. D., 1928. - Hive yeasts. - III. Bee World, 9, 154-155.

CAsteel D. B., 1912. - The behavior of the honey bee in pollen collecting. U. S. Dept. Agr. Bull., 121. 
ChevtchiK V., 1950. - Mikrobiologie pylového kvaśeni. Publ. Fac. Sci. Univ. Masaryk, 323, 103-130.

Egorova A. I., 1971. - [Preservative microflora in stored pollen]. Veterinariya, 8, 40-41.

Egorova A. I., BAB'Eva I. P., 1967. - [ Yeast flora of the honey bee (Apis mellifica L.) ]. Akad. Nauk Arm. SSSR (Ser. Biol. - Med. Nauk), 2, 127-132.

Foote H. L., 1957. - Possible use of microorganisms in synthetic bee bread production. Amer. Bee J. , 97, 476-478.

Gilliam M., Wickerham L. J., Morton H. L., Martin R. D., 1974. - Yeasts isolated from honey bees, Apis mellifera, fed 2, 4-D and antibiotics. J. Invertebr. Pathol., 24, 349-356.

Gilliam M., Morton H. L., Prest D. B., Martin R. D., Wickerham L. J., 1977. - The mycoflora of adult worker honeybees, Apis mellifera : effects of 2, 4, 5-T and caging of bee colonies. J. Invertebr. Pathol., 30, 50-54.

Kreger-VAN Ruj N.J. W., 1970. - Genus 5. Endomycopsis Dekker. In "The Yeasts: A Taxonomic Study, " ed. J. Lodder, 166-208, North-Holland, Amsterdam.

HAYdAK M. H., 1958. - Pollen - pollen substitutes - beebread. Amer. Bee J., 98, 145-146.

HAYDAK M. H., VIVINo A. E., 1950. - The changes in the thiamine, riboflavin, niacin and pantothenic acid content in the food of female honeybees during growth with a note on the vitamin $\mathrm{K}$ activity of royal jelly and beebread. Ann. Entomol. Soc. Amer., 43, 361-367.

Hгтснсоск J. D., 1956. - A milk-digesting enzyme in pollen stored by honey bees. Amer. Bee J., 96, 487489.

LAviE P., 1960. - Les substances antibactériennes dans la colonie d'abeilles (Apis mellifica L.). Ann. Abeille, 3, 103-183, 201-305.

Lemos M.V.F., MACHAdo J. O., 1975. - Caracterizacão da microflora bacteriana normal de geléia real, larvas, pré-pupas, imagos, mel e pólen da adelha Apis mellifera adansonii. Anais Congr. Brasil. Api cult., 3, 191-198.

Lodder J. (ed.), 1970. - "The Yeasts: A Taxonomic Study, "North-Holland, Amsterdam.

Miller M. W., Phaff H. J., Miranda M., Heed W. B., Starmer W. T., 1976. - Torulopsis sonorensis, a new species of the genus Torulopsis. Int. J. Syst. Bacteriol., 26, 88-91.

Okunuki K., 1943. - Úber den Gaswechsel der Pollen. V. Acta Phytochim. Japan, 13, 93-98.

Pain J., Maugenet J., 1966. - Recherches biochimiques et physiologiques sur le pollen emmagasiné par les abeilles. Ann. Abeille, 9, 209-236.

VAN DER WALT, J. F., 1970. - Criteria and methods used in classification. In " The Years : A Taxonomic Study, " ed. J. Lodder, 34-113, North-Holland, Amsterdam.

Wickerham, L. J., 1951. - Taxonomy of yeasts. U. S. Dept. Agric. Tech. Bull., 1029.

WiCkerham, L. J., Burton, K. A., 1954. - A clarification of the relationship of Candida guilliermondii to other yeasts by a study of their mating types. J. Bacteriol., 68, 594-597.

WiLson, H. F., MARvin, G. E., 1929. - On the occurence of the yeasts which may cause the spoilage of honey. J. Econ. Entomol., 22, 513-517. 